Research Article

\title{
Sustainable life cycle design aspects: how aware are material scientists?
}

\author{
Karina Vink ${ }^{1,2}$ (1)
}

Received: 21 October 2019 / Accepted: 25 June 2020 / Published online: 10 July 2020

(c) The Author(s) 2020 OPEN

\begin{abstract}
When developing new materials many aspects of sustainability are relevant, especially when the ultimate goal is mass production. More efficient energy storage and transmission are important parts of a larger product life cycle design and the confines of the circular economy, including environmental and social concerns. For example, due to environmental, geopolitical, and health concerns, it is important to choose materials that are easily accessible, as opposed to materials requiring complicated extraction, storage, and transportation methods. Equally important is the abundance of the material, as the mass production and use of a product are not sustainable if its raw components are scarce. This requires material scientists to be aware of how their design affects the later life cycle stages of the materials they develop. Very few studies cover whether material scientists take these type of questions into consideration. To resolve this, material scientists were questioned on various sustainability aspects. Results show that most of the questioned scientists have little to no awareness of what effects mass production of their developed materials might have regarding greenhouse gases or the workforce, or what their material's recyclability or longevity might be. The results indicate that these questioned material scientists are not fully aware of several imperative sustainability aspects and do not fully consider the impacts of their designs. To increase instilling and evaluating awareness of sustainability aspects on life cycle design, two improvements are: increasing sustainability education by lifelong learning, and adding sustainability concerns as a required component to grants and funding.
\end{abstract}

Keywords Sustainable design $\cdot$ Material science $\cdot$ Life cycle $\cdot$ Material design

\section{Introduction}

Sustainability has many meanings depending on the subject under consideration. In this study "sustainable design" refers to designing materials and manufacturing processes in such a way as to minimize consumption and waste, while supporting fairness and prosperity for all (see also "sustainable lifestyles" as defined by the United Nations Environment Programme [1]). As seen in Fig. 1, this requires taking into account the entire life cycle of a material, from conception to waste. It also requires considering multiple dimensions of sustainability that are affected: economic, environmental, and social. "Sustainable design of a new material" as used in this study can refer to a new material itself, a new device to measure materials, or even a new manufacturing process, all relating to the research and development of materials science.

Designing materials to have sustainable life cycles, or improving existing materials and manufacturing processes towards that goal, is ethically desirable, economically favorable, and allows for continuous flexible adaptation to future changes. The process of designing new materials or

$\triangle$ Karina Vink, karinavink@gmail.com | ${ }^{1}$ Technology Integration Unit, Global Research Center for Environment and Energy Based on Nanomaterials Science (GREEN), National Institute for Materials Science (NIMS), 1-1 Namiki, Tsukuba, Ibaraki 305-0044, Japan. ${ }^{2}$ Present Address: Water Engineering and Management (WEM) and Construction Management and Engineering (CME), Department of Engineering, Faculty of Engineering Technology, University Twente, Horst Building Nr. 20, Postbus 217, 7500 AE Enschede, The Netherlands. 


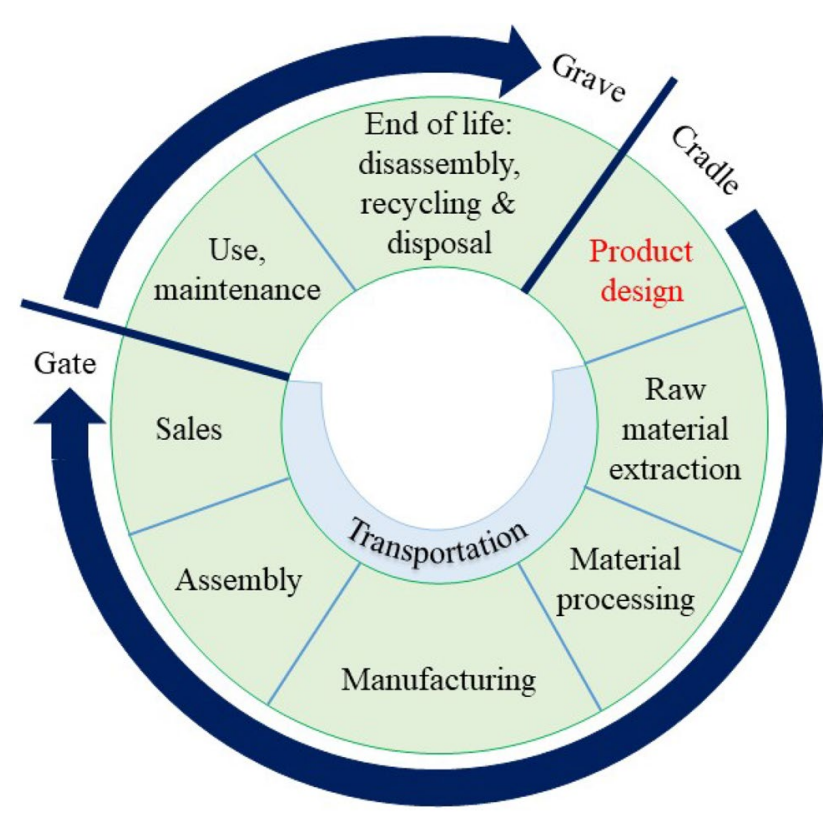

Fig. 1 Life cycle phases of a product

processes to produce them is developed by material scientists, who are interdisciplinary researchers with knowledge of applied physics, chemistry, and engineering [2]. When sustainability is not taken into account during the product design phase, we can end up with products and manufacturing processes that lead to unethical resource exploitation, environmental damages and health issues, nonrecyclable waste, and additional loss of money and time dealing with these new problems. Mulder et al. [3] point out how solving only one aspect of sustainability may lead to seriously undermining and even reversing progress for other sustainability aspects. UNEP [1] shows that mining resources commonly leads to biodiversity loss, deforestation, greenhouse gas emissions, and involves toxic chemicals, and that we have globally tripled resource extraction over the past 40 years. Yet, sustainable design is not merely important now that we as humans are overcrowding the planet and running out of resources to continue current consumption patterns, but also from an ethical perspective for equity and the environment in principal. An example of unsustainable design and inequity is when a base material is chosen of which it is known that local inhabitants do not profit from its extraction and their direct living environment is degraded without compensation. On the other hand, if manufacturing organizations pursue the Sustainable Development Goals (SDGs) actively, an estimated US\$12 trillion could be generated yearly as well as 380 million jobs, and thereby lower poverty, provide a more equal income distribution, and increase human development rankings [4]. However, [4] emphasize that the industry contribution to the SDGs policies should be aimed at the life cycle phases of production, consumption, and waste management, and do not mention the design phase of products' life cycles. A close examination of the targets of SDG 12 (ensuring sustainable consumption and production patterns) shows that targets do not consider the design of materials specifically either [5]. These two points are striking, as Skerlos et al. [6] show that over $80 \%$ of a product's environmental impacts results from decisions made during the design phase of the product's life cycle. Therefore, materials need to be designed as sustainable as possible from the very first design phase: material research and development, and include considering impacts from multiple aspects.

In short, when considering what a sustainable material is, we must look at the entire consumption and production cycles, of which design is a part. The green economy is a concept that envisions an idealized version of SDG 12 . To define the green economy, the UNEP [7] applied the trinity of improved human well-being and social equity, reduced environmental risks, and reduced scarcities. Material cycles should involve low-carbon and pollution pressures, be resource efficient, and be socially inclusive [7]. Similarly, the UNEP in 2016 speaks of people, planet, and profit, and calls to develop product sustainability information that helps achieve sustainable consumption, which brings about a better quality of life and alleviate poverty, while minimizing resource use and toxic materials or pollutants during the life cycles of products and services [8].

For the purposes of this study, I therefore define that a material can be said to be sustainable if its entire life cycle, including design, production and consumption, transportation, re-use and end-of-life, are taken into account from all perspectives of possible impacts on human well-being, be it social, economic, or environmental, and negative impacts are excluded as much as possible. This way people can make better choices to 'protect the environment, improve the lives of the people who produce the goods, and safeguard the health of people who use them', including future generations [7]. The International Resource Panel (IRP) states that given the complex interrelations between human, economic, and environmental well-being, progress in one of these may hinder progress in the others [9]. The IRP further prescribes that the economy must become circular through the intelligent design of products.

To consciously design materials and processes in a sustainable way, one must first be aware of which aspects of sustainability come into play during the life cycle of the material or process under development. While sustainable life cycles are already well developed in the field of product design by means of tools for selecting various manufacturing, supply chain, and end of life options [10], this is still under development for the material sciences, 
where new materials and processes might be used on a mass scale and thus affect supply chains on a global scale for multiple decades. Without education on sustainability, researchers may not be aware of the potentially far reaching consequences of their choices for novel materials and processes.

Several educational institutions have begun offering courses on sustainability or integrated the topic within existing curricula, with the goal of preparing students for the real life ethical, scientific, and economic choices concerning which materials to apply and how to develop new ones [11]. This would suggest that young material scientists have a certain level of awareness of creating materials with sustainable life cycles. However, at the moment there is very little research indicating how well informed current material scientists are about sustainable design, and how they are putting these crucial aspects into practice when developing new materials. The objective of this study is therefore to evaluate material scientists' awareness of sustainable life cycle aspects of the materials they are currently developing; and to subsequently increase the number of studies on the subject.

\section{Methods}

This section firstly describes the construction of a framework based on existing literature used for the development of the questions posed to material scientists, and secondly describes how the respondent's answers were gathered and scored.

\subsection{Literature leading to questionnaire framework}

The current state of development of sustainable design principles has a long history before it. The green chemistry principles described by Garg [12] (summarized in Table 1) are one of the earliest efforts towards a more sustainable production process in the field of chemistry, however they do not encompasses the entire spectrum of sustainability. Examples of this can be found in recent studies applying these principles, which do not take the wider sustainable development goals such as the consequences for ecosystems or livelihoods into consideration, and can thus not be considered to practice sustainable design (e.g. [13, 14]). Gopalraj and Kärki [15] do examine the environmental and economic effects of a material but look at recycling and closing the loop to stimulate the circular economy. They do not include the design of the material into their study, thus foregoing to examine if significant change from the very beginning of the process is possible [15]. A recent review of green chemistry applications [16] lists many examples of sustainably designed products, but these prove to be exceptions rather than the norm, and appear to be driven by economic profit potential rather than actually addressing the most unsustainable processes first, including reducing resource use. The author further suggest that the "next generation of chemists should be taught the basics of green chemistry at a very early stage so that they can think green and develop safer methodologies", implying this is not yet the case, and implying it is pertinent to examine how sustainability principles are being taught in the curriculum of material scientists.

Therefore, the first step in creating a framework of relevant sustainability aspects, of which material scientists are considered to ought to be aware of, is to examine the existing literature on the education of sustainable design. Currently the number of studies concerning the education of material scientists regarding sustainable design aspects is scarce. A search on Web of Science using the keywords 'sustainability'/'sustainable,',education', and 'materials science' revealed a mere eight unique and relevant results (performed February 2017). Based on this, in this study material scientists were defined as anyone involved in the development of new materials, which includes both chemists and engineers. While this enlarged the range of potentially relevant targets for education, additional searches with these keywords using google scholar remained limited. Nevertheless, two types of results were found, namely literature related to either academic courses or recommended curricula, and literature related to codes of ethics and suggested guidelines, which are both summarized in Table 1.

As a synthesis of Table 1, literature from chemistry focuses on reducing or eliminating the use of pollutants and toxic compounds. Materials science and engineering literature covers recycling, reduced energy and resource consumption, enabling a cleaner environment and less toxicity, as well as accessibility and geopolitical forces, the economy, and individuals' social needs. Engineering literature comprises minimizing pollution, environmental and social impacts, energy requirements, and increasing longevity, recycling; as well as adding educational topics on population, environment, and development. The geosciences literature highlights the public's health and safety, efficient resource management, and recommend to include ethical reflection, sociology, and economics into the curriculum. Literature covering all students stress enabling a low-carbon future, with due consideration for energy justice of current and future generations. Other literature emphasize the importance of shadow pricing in cost-benefit analyses obscuring costs of environmental and social resources, again including future generations, the need to reduce GHG emissions and pollutants, and to create new jobs and new technologies. 


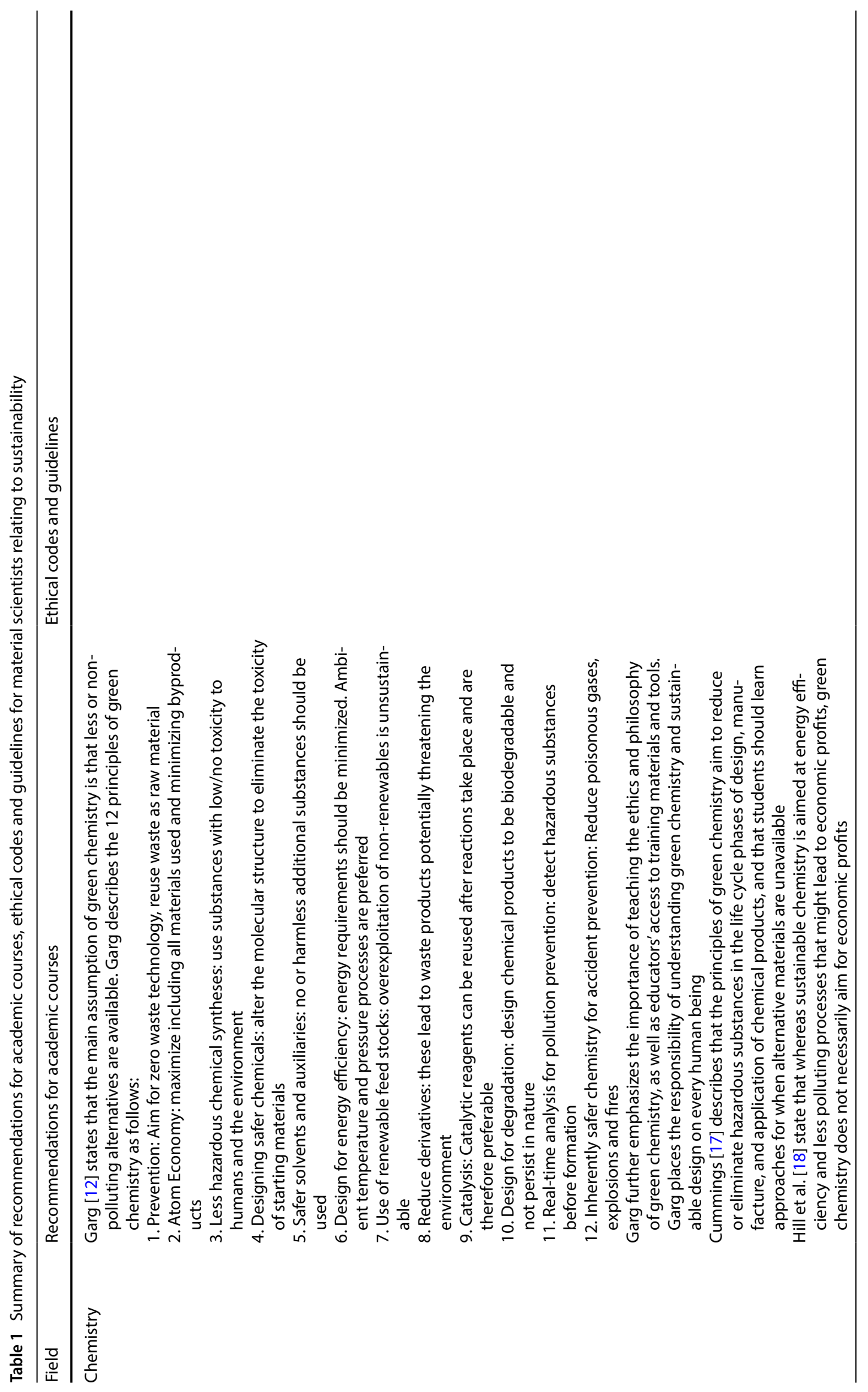




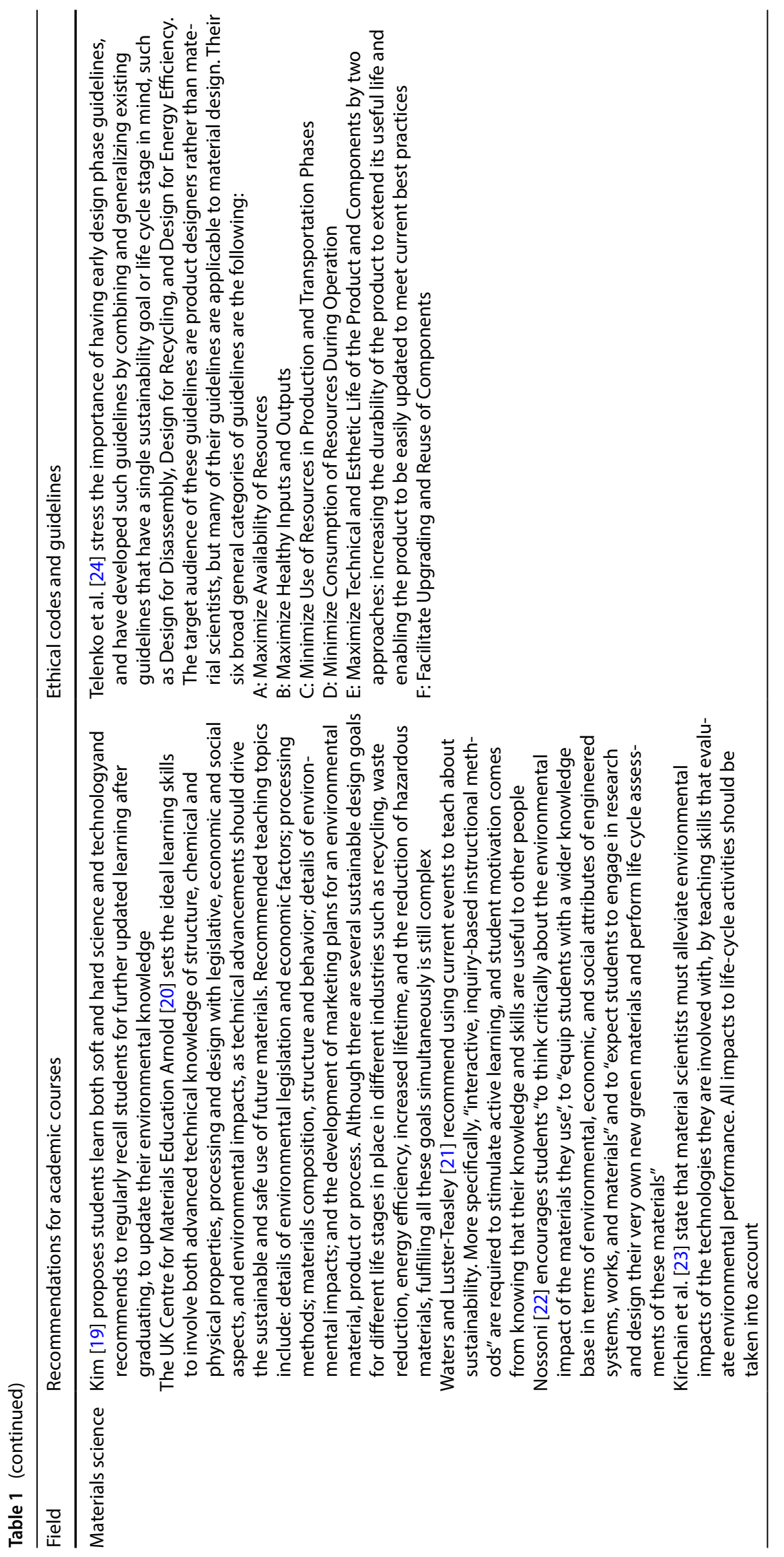




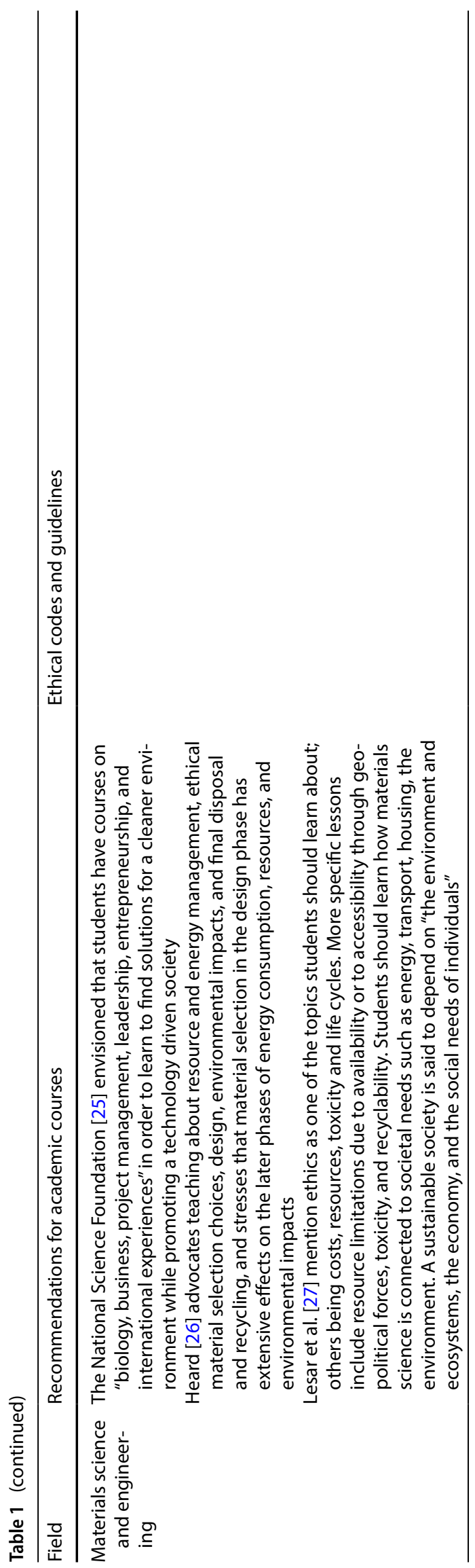

\section{SN Applied Sciences}




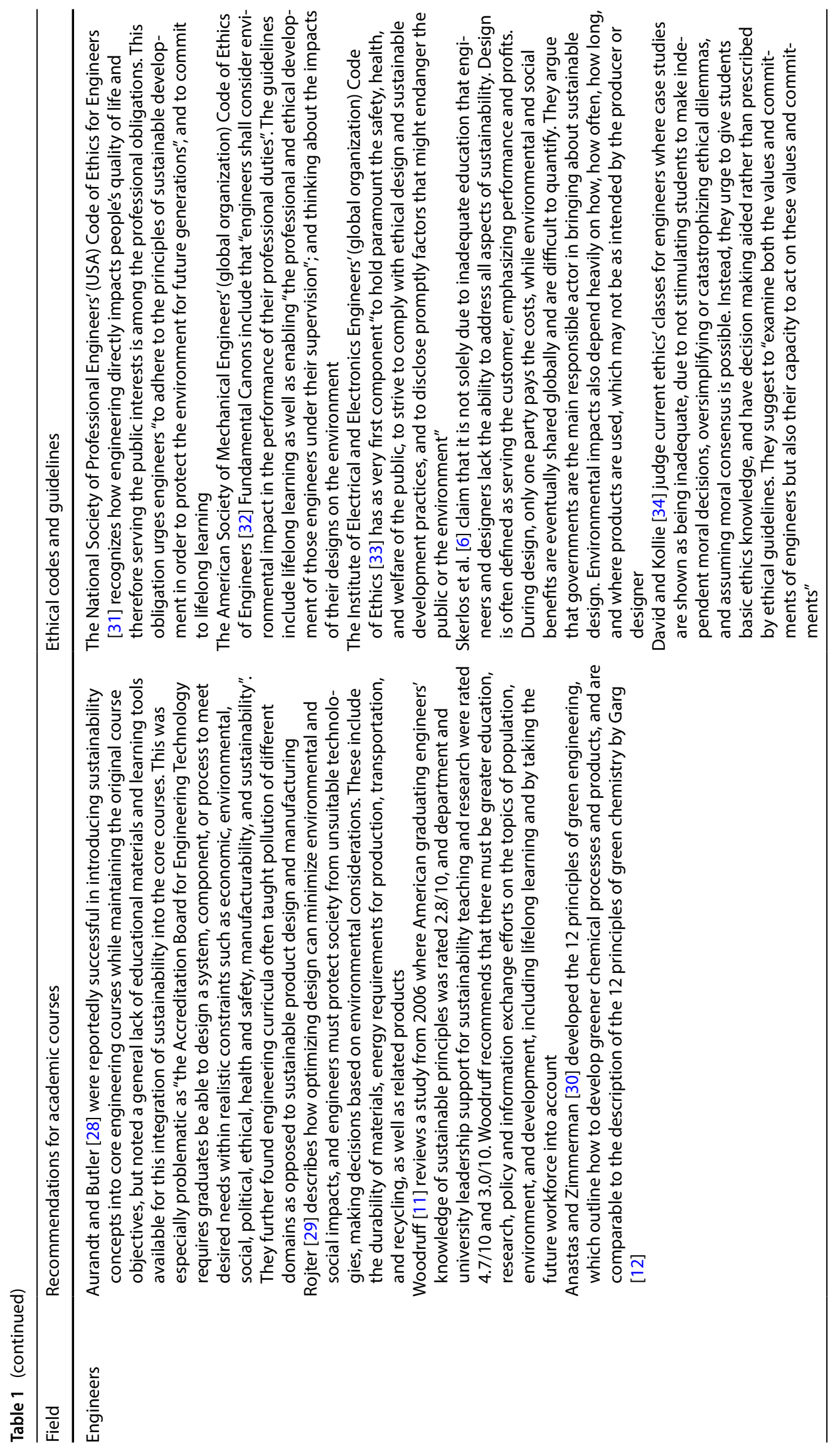




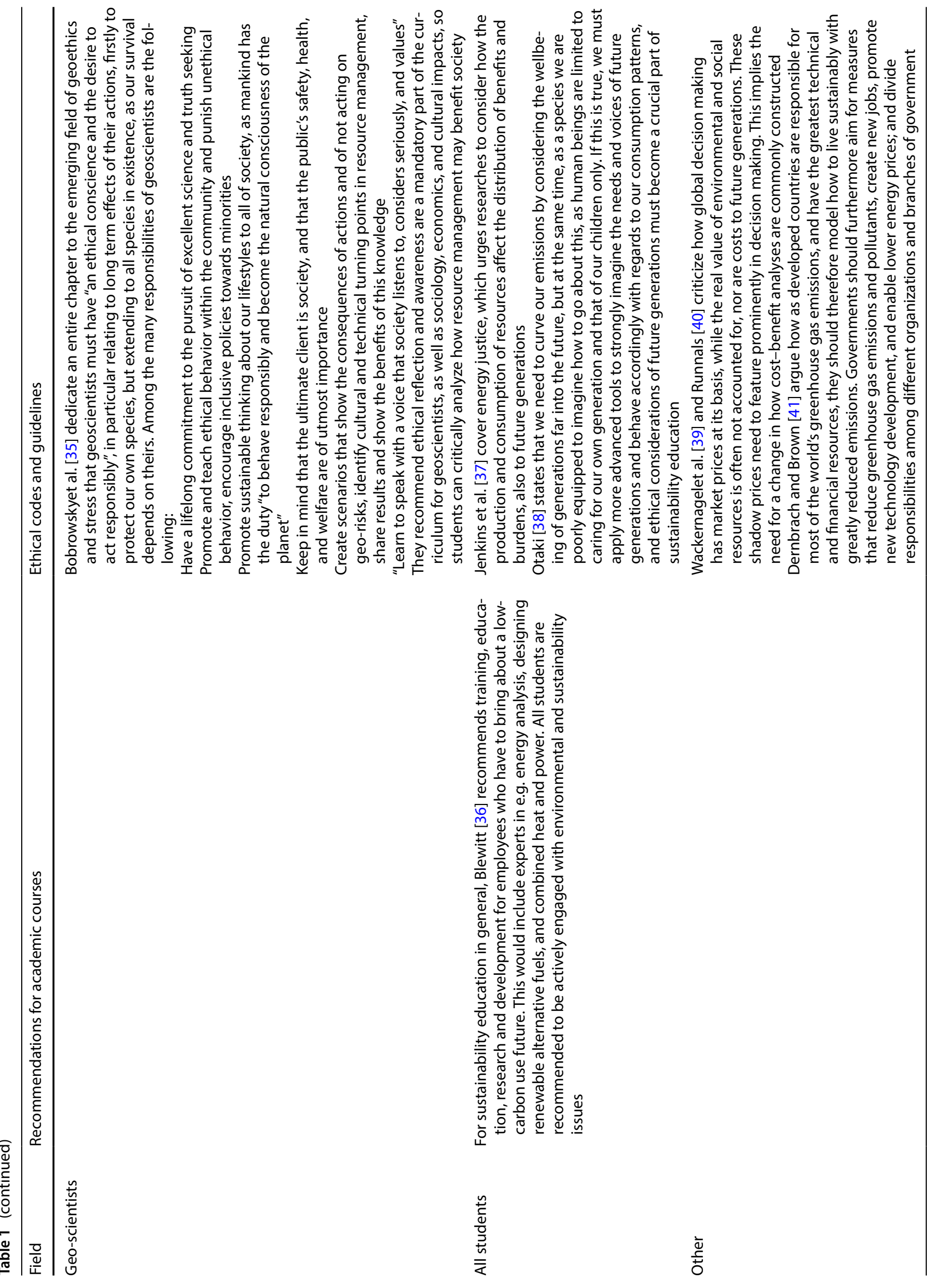


The combined results from the reviewed literature were converted into the following four categories of sustainability and form the basis for the questions posed to material scientists.

- Efficiency, lifetime, and recyclability of the material

- Abundance and accessibility of resources

- Emission of GHG and toxic substances during manufacturing, supply chain, and end of life, to humans and the environment

- Effects on livelihood in the form of job creation and the availability of sufficiently trained personnel

The logic behind these categories is as follows. Various literature in Table 1 stress resource efficiency, longevity, and recyclability. For the latter, the UNEP [42] shows that recycling is crucial, not just from the perspective of the circular or green economy. Mining and refining metals are currently costing $8 \%$ of global energy supply and causing GHG emissions, whereas recycling is much less energy intensive, and especially metals can be recycled almost indefinitely [42]. For the second category, accessibility and abundance are viewed mainly from the perspective of successfully developing materials that help enable a more sustainable life, which would thus be mass produced and applied globally. A higher accessibility and abundance would then help enable localized production and reduce global tensions or monopolies, for current and future generations.

As with the first category, various literature in Table 1 stress the need to reduce emissions of GHG, pollutants, and substances toxic to humans and the environment which are in the third category. Both the first and third categories are also voiced by the International Resource Panel [43], who envision "a new economic paradigm to improve resource productivity" by reducing resource and energy consumption, wastes, and emissions. This would include mapping impacts such as pollution, deforestation, biodiversity loss, water depletion, health, well-being, and wealth, by means of resource flows and life cycles [43]. The fourth category, like the second, is based on the consequences of successfully developing materials which would be applied on a global scale and thus replace existing industries. This would in turn greatly affect the economy, including livelihoods, work force, and required knowledge and skills. The questions correlate to UNEP's green economy [7], the profit and people side of sustainability [8].

In order to minimize task difficulty and maximize respondent motivation, the questionnaire was designed to be short, having 10 questions total [44]. This led to the following questions (including one separate question on the researcher's topic):
1 How much more efficient is this material in comparison to conventional materials?

2 How much longer is the lifetime of this material in comparison to conventional materials?

3 How rare or hard to obtain are the base components?

4 If the entire world would need to be supplied with this material for daily use, would there be enough of it for several future generations?

5 How many greenhouse gases are released during the production process of this material?

6 How toxic are the materials used to humans and the environment?

7 How much of this material can be recycled at the end of its life cycle?

8 How much training and education would be required to start mass production of this material?

9 How many new jobs would be created in order to mass produce and maintain the use of this material?

This level of detail of questions concerning the product life cycle and social-economic impacts gives an initial insight into the level of consideration of sustainable aspects material scientists have. To a lesser extent, it could be used as an indicator to measure to what degree they consider themselves responsible for how their work continues after their design and development. It is noted that the level of detail of these questions may measure knowledge rather than awareness of sustainability.

\subsection{Data gathering and scoring}

The knowledge of material scientists was assessed during three events. The participants of the first and second event were presenting their work at these events and as such can be said to be material scientists. The third event consisted of material scientists and scientists working on new materials and techniques for material sensors.

The first event was a symposium for material scientists held at a research institute in Tsukuba, Japan in March 2017. For this event a list of ten questions was developed. Over the course of three days, 14 scientists were interviewed in person. Actual interviews depended on researcher availability over the course of the symposium. Interviews lasted roughly $15 \mathrm{~min}$. Participants were first asked to describe the object of their study. All materials/ devices were related to improving energy storage, energy transmission, or other technical optimizations. Participants were then asked to envision a future where their material/ device had become successful to the degree that production would be scaled up to allow mass production on a global scale.

The answers to the questions were rated qualitatively on a scale of $0-5$, with 0 equating to 'no idea'. A score of 0 
therefore indicates whether or not participants consider themselves aware of the sustainability aspect. Further scoring divided into values of 1-5 provided more insight into how sustainable they judge their materials to be. For each question, answers rated 1 were less ideal and answers rated 5 were most ideal. Table 2 shows the qualitative scoring per sustainability aspect to which participants' responses were scored. Since few participants knew how to estimate the greenhouse gas emissions during production, they were alternatively asked to describe the highest temperature process in order to estimate energy use.

For the second and third events, a questionnaire was handed out to attendants of the poster sessions or workshop attendants, who were either presenters or visitors. The second event was a symposium held in June 2017 and the third a workshop held in August 2017; both events were aimed at material scientists and held at a research institute in Tsukuba, Japan. The ten questions and scoring options were virtually the same as described above and can be found in the appendix. Due to the nature of the questionnaire there was no opportunity to ask participants about the highest temperature process in the development of their materials. The age of participants of all three events was estimated to be between 20 and 40 years, with all participants having completed at least a master's degree in a field related to material sciences. The respondents were of various nationalities (Asian, European, American) and working as researchers in the field of material science.

Responses were anonymously combined per event and for all three events together. A further distinction was made between the mean per question including all responses, and excluding responses with a score of ' 0 ' for 'no idea'. The range and prevalence were also calculated per question. The topic of one participant of the first event was found to be purely theoretical, and was therefore excluded from the results. This participant did comment that the questions were interesting to think about. On two occasions a participant had responded with a value lying in between two scores. In these specific cases, the value of 1.5 or 2.5 was attributed, and for prevalence a similar 0.5 value was attributed to the respective scores. On three occasions a participant did not give a score. This led to the total number of responses being 35 for the aspects efficiency, training, and workforce; and 36 for all other aspects.

\section{Results}

\subsection{Scores per sustainability aspect}

Table 3 gives an overview of the average of the scores per sustainability aspect, for all events combined, and for both with and without taking into account the scores of 0 (no idea). When considering the individual events, the minimum and maximum attributed scores (excluding 0 ) ranged from 1 to 5 for every aspect except for efficiency (range 2-5) and greenhouse gases (range 3-5), as can be seen in Fig. 2.

Overall, the sustainability aspects where participants judged themselves the most to have no idea (score 0 ) were greenhouse gases ( 31 responses, $86 \%$ ), recyclability (16 responses, $44 \%$ ), longevity (13 responses, 36\%), and workforce (12 responses, $35 \%)$. The aspects of which most people displayed awareness were accessibility $(97 \%$, only

Table 2 Qualitative scoring per sustainability aspect (see Sect. 2.1 for full questions)

\begin{tabular}{|c|c|c|c|c|c|}
\hline Score & 1 & 2 & 3 & 4 & 5 \\
\hline Efficiency & $\begin{array}{l}\text { Orders of magnitude } \\
\text { worse }\end{array}$ & Worse & Comparable & $2-10 \times$ more efficient & $100 \times$ or more efficient \\
\hline Longevity & $\begin{array}{l}\text { Orders of magnitude } \\
\text { worse }\end{array}$ & Worse & Comparable & Years & Decades \\
\hline Abundance & Very rare & & Common & & Highly abundant \\
\hline Accessibility & Difficult & & Average & & Easily \\
\hline Greenhouse gases* & $\begin{array}{l}\text { Massive- }-500,000 \mathrm{~kg} \\
\mathrm{CO}_{2} \text { equivalent }\end{array}$ & $\begin{array}{l}50,000 \mathrm{~kg} \mathrm{CO} \mathrm{CO}_{2} \text { equiva- } \\
\text { lent }(2-3 \text { cars })\end{array}$ & $\begin{array}{l}500 \mathrm{~kg} \mathrm{CO}_{2} \text { equiva- } \\
\text { lent }\end{array}$ & $\begin{array}{l}50 \mathrm{~kg} \mathrm{CO} \text {, equivalent } \\
\text { (pc) }\end{array}$ & $\begin{array}{l}\text { Few to none }-5 \mathrm{~kg} \\
\mathrm{CO}_{2} \text { equivalent } \\
\text { (food stuffs) }\end{array}$ \\
\hline Toxicity & $\begin{array}{l}\text { Numerous adverse } \\
\text { effects }\end{array}$ & $\begin{array}{l}\text { Several adverse } \\
\text { effects }\end{array}$ & Some adverse effects & Few adverse effects & No adverse effects \\
\hline Recyclability & $\pm 0-5 \%$ & $\pm 25 \%$ & $\pm 50 \%$ & $\pm 75 \%$ & Up to $100 \%$ \\
\hline Training & $\begin{array}{l}\text { Beyond university } \\
\text { degree }\end{array}$ & Master's Degree & Bachelor's Degree & High school diploma & None \\
\hline Workforce & Few $-100 \mathrm{~s}$ & $1,000 \mathrm{~s}$ & $10,000 \mathrm{~s}$ & $100,000 \mathrm{~s}$ & $1,000,000 \mathrm{~s}$ \\
\hline
\end{tabular}

* Based on http://www.co2list.org/files/carbon.htm 
Table 3 Average score per sustainability aspect for combined events, including \% of respondents without '0' entries (color coded ranging from green for ' 5 ' entries to yellow for ' 0 ' entries)

\begin{tabular}{|c|c|c|c|c|c|c|c|c|c|}
\hline Aspect & Efficiency & Longevity & Accessibility & Abundance & $\begin{array}{l}\text { Green- } \\
\text { house } \\
\text { gases }\end{array}$ & Toxicity & Recyclability & Training & Workforce \\
\hline With '0' entries & 2.57 & 1.83 & 3.94 & 3.58 & 0.58 & 3.31 & 1.61 & 2.44 & 1.56 \\
\hline \multirow[t]{2}{*}{ Without ' 0 ' entries } & 3.21 & 2.87 & 4.06 & 3.79 & 4.20 & 3.61 & 2.90 & 2.67 & 2.37 \\
\hline & $80 \%$ & $64 \%$ & $97 \%$ & $94 \%$ & $14 \%$ & $92 \%$ & $56 \%$ & $91 \%$ & $66 \%$ \\
\hline
\end{tabular}

1 entry of 0 ), abundance (94\%, 2 entries of 0 ), and toxicity and training (92-91\% respectively, both 3 entries of $0)$. Interestingly, accessibility and abundance simultaneously were rated highest, with 27 and 22 responses scoring either 5 or 4 . The aspects of which training and workforce were rated lowest, with 14.5 and 15 responses scoring either 1 or 2.

\subsubsection{Efficiency}

For the first event, the efficiency of the participants' materials was on average comparable to conventional materials used. Overall, participants responded that their material was either worse, comparable, or several factors more efficient. One participant in the second event did not answer this question. One respondent commented that since many of the materials are still in development and being improved upon, it is unlikely that any larger scale commercial application will occur until several factors of increased efficiency are attained.

\subsubsection{Longevity}

A rather large number of participants of the events (25-46\%) had no idea about the longevity of their material. As these projects are still in development, for many projects it is still unknown how long the material would remain performing up to desired standards, especially since these standards evolve along with the capabilities of available materials.

\subsubsection{Accessibility}

The majority (11/13) of participants of the first event stated their materials are easily accessible (score 5 ). The remaining two participants rated the accessibility of (some of) their materials with the lowest score of 'very rare', which made this a highly polarized response. The second and third events saw more spread for the rating of accessibility. Still, more than half $(6 / 11)$ of the participants in the second event rated accessibility as 'easily' (score 5 ). In the third event most of the participants (8/12) rated accessibility as 'reasonably obtainable' (score 4 ) as the highest score.
No one in the second and third event rated accessibility as 'very difficult' (score 1).

\subsubsection{Abundance}

The majority (10/13) of participants of the first event judged the materials used for their project as highly abundant (score 5). One participant indicated 'common' abundancy (score 3), one 'very rare' (score 1), and one 'no idea' (score 0 ). This means the majority of participants judged there would be sufficient material available on earth to produce their material for use in daily life of current and future generations. For the second and third event this appraisal changed. In the second event only 2 participants responded with score 5 , while the majority $(6 / 11)$ rated abundancy with high abundance (score 4 ) and the remainder with scores of 2 or 3 . In the third event no participants responded with score 5 , and the majority (9/12) rated abundancy with either score 3 or 4 .

\subsubsection{Greenhouse gases}

Three out of 13 participants of the first event were optimistic and estimated the production process of their materials would result in few to no greenhouse gas emissions, which was motivated either by there being no heating or the processes occurring at room temperature. The remaining participants indicated having no idea. In the second event, the majority $(9 / 11)$ of respondents had no idea, and two participants responded with scores of 3 and 4 each. In the third event all 12 participants reported having no idea. This implies most participants did not consider the emission of greenhouse gases during design of their materials.

\subsubsection{Toxicity}

For the first event, while all of the possible scores occurred in the answers, the most prevalent were the scores of 'some adverse effects' (score 3) for 5 out of 13 participants, and 'no adverse effects' (score 5) for 4 out of 13 participants. Only one participant had no idea about the toxicity of the materials, and only two participants rated their materials as having numerous or several 


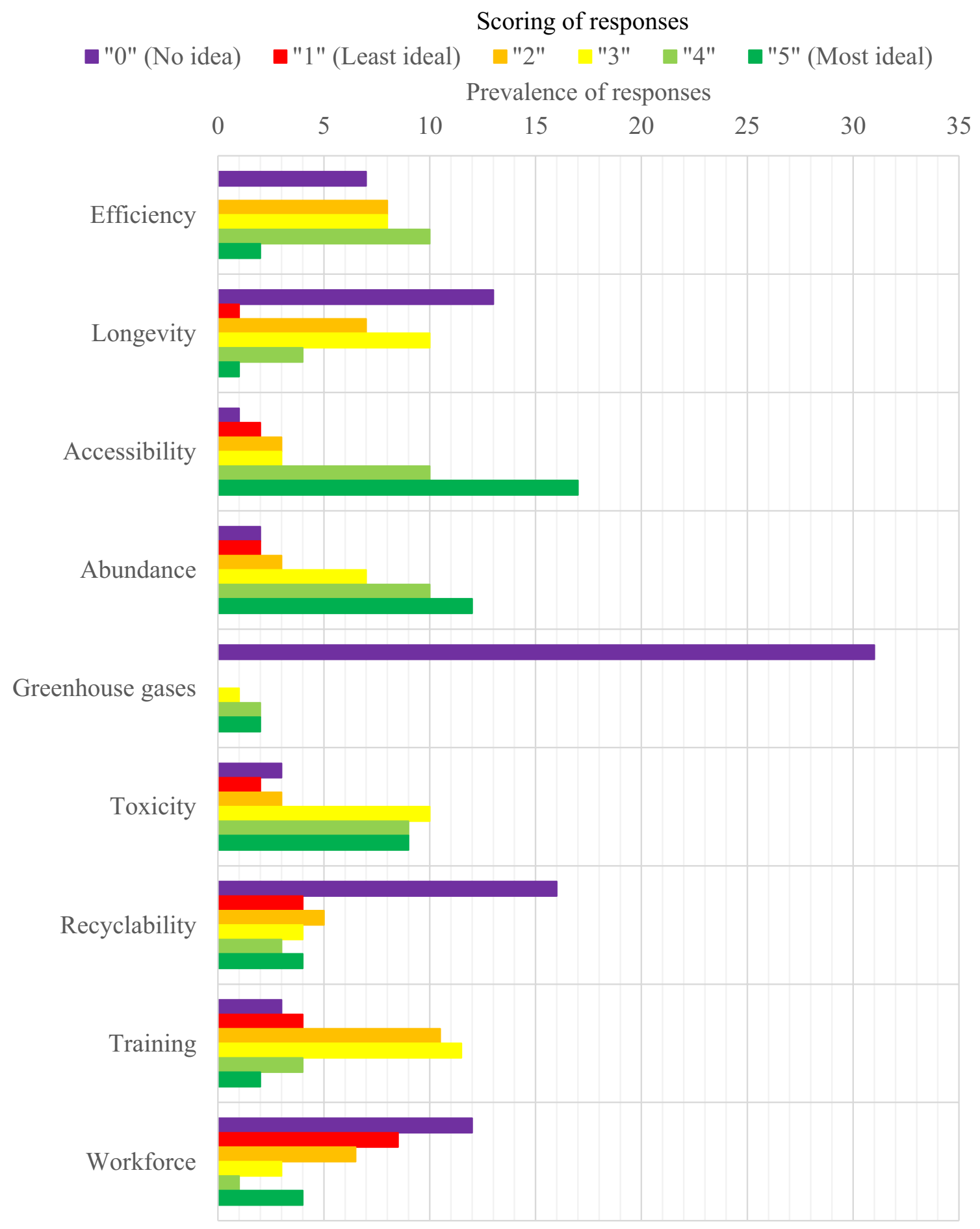

Fig. 2 Prevalence of respondents' scores per sustainability aspect (combined results from 3 events)

adverse effects. For the second event all participants had some idea of the toxicity of their material, and 5 out of 11 participants rated it as 'no adverse effects (score 5). For the third event two participants had no idea (score $0)$. All participants having some idea (10/12) rated the scores between 2 and 4 .

\subsubsection{Recyclability}

Nearly half of the participants (6/13) of the first event had no idea (score 0 ) about the recyclability of their materials. Another 6 responded they estimated recyclability would be around $25-50 \%$ (scores $2-3$ ). One participant stated 
$100 \%$ could be recycled (score 5). For the second event, two out of 11 participants had no idea (score 0 ) of the recyclability of their materials/devices. Only 1 participant indicated close to no recyclability (score 1), whereas most participants reported recyclability from 50 up to $100 \%$ (scores 3-5). Results from the third event were more like the first event, with $8 / 12$ participants reporting no idea (score 0 ) and further scores of 1-2.

\subsubsection{Training}

One participant of the first event indicated this question was not applicable; thus no response was taken into account. Of the remaining 12 participants, 5 indicated a high education in the form of a master's degree or higher would be necessary to produce their material (score 2). A further 3 indicated a bachelor's degree would suffice (score 3 ), and 2 estimated a high school diploma would suffice (score 4). One participant stated no education was necessary as the production process was quite simple (score 5). For the second event, two out of 11 participants had no idea (score 0 ) of the amount of training and education required for the production of their materials. Only one participant indicated training beyond university would be required (score 1), whereas the majority $(7 / 11)$ reported a bachelor's or master's degree would be required (scores $2-3)$. For the third event, only 1 out of 12 participants had no idea (score 0$)$. The majority $(10 / 12$ ) had scores ranging from 1 up to 3 .

\subsubsection{Workforce}

One participant of the first event indicated this question was not applicable; thus no response was taken into account. Two participants indicated to have no idea (score 0 ). The remainder of participants conveyed on average a keen awareness of the potential markets or industries related to their material, and thereby logically argued for the number of potential jobs that could be developed, which varied widely. The second event had dramatically different responses with 7 out of 11 participants having no idea (score 0 ), and three participants estimating a few to 1,000 s of jobs being created (scores 1-2). One participant estimated the creation of millions of jobs (score 5). For the third event, three out of 12 participants had no idea (score 0 ), and the majority (8/12) estimated a few to $1,000 \mathrm{~s}$ of jobs being created (scores 1-2). One further participant estimated $10,000 \mathrm{~s}$ of jobs might be created (score 3 ).

\subsubsection{Scores per event}

Figure 3 shows the differences in prevalence of scores between events. Since the results of event 1 were gained

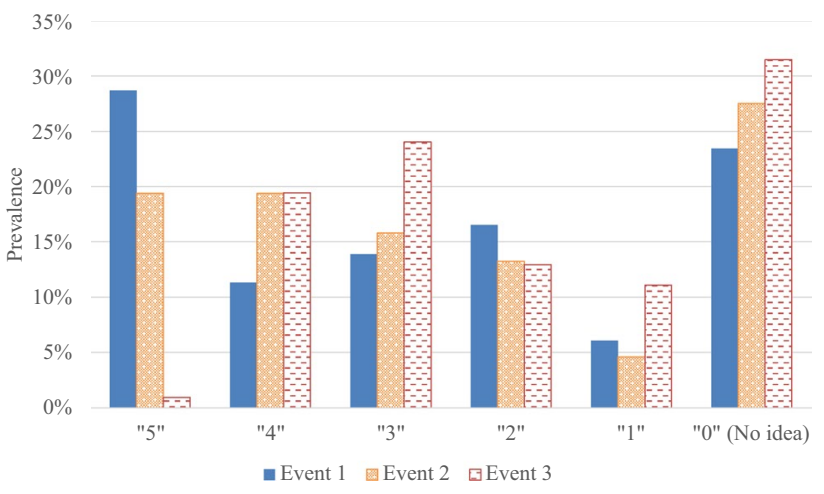

Fig. 3 Prevalence of scores per event for all aspects combined

by direct interviews and events 2 and 3 by means of questionnaires, a potential difference in scoring between these was anticipated. However, results overall show no significant difference between the scoring for events 1 and 2 . Event 3 shows the largest difference from the other two events for the score of " 5 ", which is given only once for one aspect. It also has the highest number of scores for " 0 " (no idea), indicating higher uncertainty. Total scores per event and per aspect (Fig. 4) highlight the varied responses per event, dismissing a significant difference in responses between interviews and questionnaires.

\subsection{Highest degree temperature process}

Participants of the first event were asked to estimate the highest degree temperature Celsius of their combined production processes (see Fig. 5). The time taken for each of these processes varied widely from $10 \mathrm{~min}$ to several days. Most of the processes $(8 / 13)$ occurred up to $80^{\circ} \mathrm{C}$; the remaining 5 ranged between 140 and $450^{\circ} \mathrm{C}$. None of the values qualified as outliers as per the Tukey formula of $1.5^{*}$ interquartile range. Two participants did not answer this question.

\section{Discussion}

\subsection{Interpretation of results}

Within the confines of this study, the sustainability aspects of which participants judged themselves the most to have no idea of were greenhouse gases, recyclability, longevity, and workforce. For these respondents, these sustainability aspects are not yet fully understood in relation to the materials they are designing. Furthermore, the aspects scoring high most often were accessibility, abundance, and toxicity. The aspects scoring low most often were training and workforce. It is prudent to verify how these aspects 


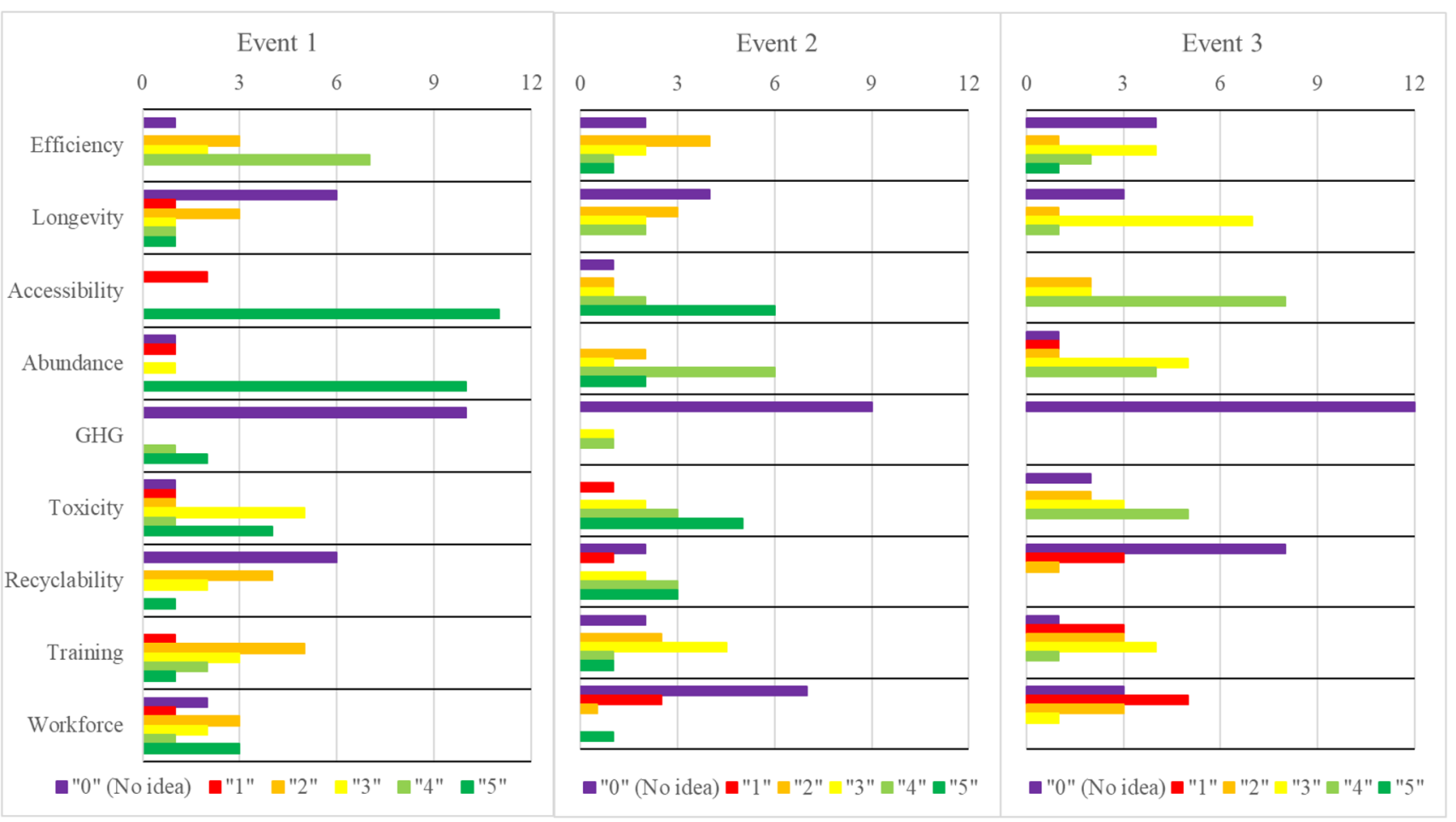

Fig. 4 Prevalence of score per event and per aspect

Fig. 5 The estimated highest degree temperature Celsius of the production processes (made with http://www.imath as.com/stattools/boxplot.html)
Estimated highest degree temperature Celsius of production processes

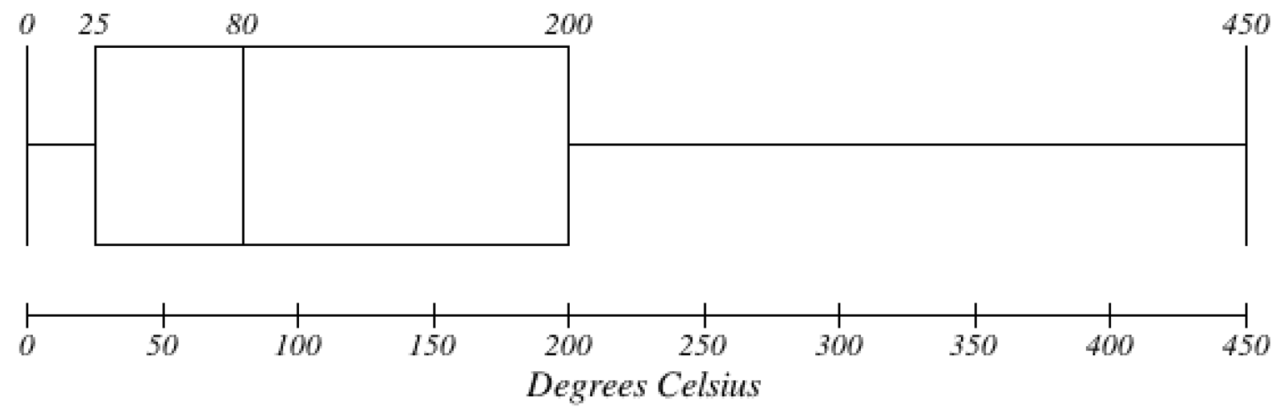

might actually score and relate education goals and verification of knowledge based on these results. Training and workforce currently score high when education levels are low and many new jobs are created, though this may arguably be viewed differently (see methods). However, if a reversed scoring system had been applied, this would not have changed which aspects score the highest overall.

It is noted that the questions reflect more the knowledge of how the material development process might impact detailed sustainability aspects, rather than merely the awareness of which sustainability aspects exist and might be influenced. Awareness itself can be evaluated as responding with values that are not 'no idea'. The subsequent scoring provides additional insight into which knowledge of the impacts the material scientists judge themselves to have.

It is important to keep in mind that these scores are based on the participants' own judgment as experts in the fields respective to the material they are developing. These scores however do not necessarily reflect reality. For instance, are the base materials really as easily accessible as many respondents have judged? The quantities required for experimental designs might be readily available, but for mass production, the volatility of global supply 
chains and how this might directly and indirectly affect production of their material can lead to strongly reduced access. Actual scores would be more suitably evaluated by a life cycle analysis study. If these scores accurately reflect reality, there is much to be improved in relation to job creation and training.

Regarding the logic behind the questions, the ideal situations envisioned can have several influences reducing their desired status. For example, efficiency of a material is also technology dependent. There can exist tradeoffs between more efficient materials and more efficient technologies and processes, which have not been examined in these ten questions. Comparably, a higher accessibility might lead to overconsumption if there are no simultaneous measures to stimulate production in line with the needs of future generations. Furthermore, it can be argued that a production process requiring few workers is preferable, as it is easier to set up. However, the development of a new material is envisioned, that in an ideal case would replace existing technologies and thereby affect current livelihoods. Therefore, providing more people with a steady income is seen as the preferable sustainable situation for overall society. For this same reason a minimum of education is seen as preferable over long years of training, as this would increase the number of years someone can have a productive income. It is acknowledged that a longer education could lead to a higher income and simultaneously create more educational jobs, but this was not taken into account in the questionnaire.

As for the highest temperature during manufacturing, this may provide an initial indication of how much energy is required to produce the materials. Depending on the energy source, this can contribute more or less to climate change. What is still missing is an indication of how long these highest temperature processes last, and if there are many different high temperature processes or merely a single manufacturing step requiring this temperature. Moreover, an indication of how much of the manufacturing process could be supplied by locally generated renewable energy, and how various manufacturing emissions could be captured and neutralized, would be ideal. The fact that the majority of the respondents of the first event where this question was posed could easily give their estimation implies a strong awareness among participants of the technical side of manufacturing their materials.

\subsection{Implications}

These results mainly imply that material scientists are not yet considering and applying all relevant aspects of sustainability when designing new materials, which in turn could have grave consequences if their material proves successful and is mass produced in the future. Improving this situation begins in education, however, teaching sustainability aspects has its own hurdles. While the SDGs are ideally taught as early as in elementary school, many schools face issues integrating the topics in the already overcrowded curriculum. In the Netherlands for instance, "only a few elementary schools teach sustainability. The requirements of elementary school teachers on sustainability as set by the UN in 2011 are not applied in practice, as there is more emphasis on math, language, geography, nature, and history" [45]. We need to recognize these challenges and allow for more budget and resources to transform current education at all levels and ensure future students of all fields are well informed.

That being said, merely teaching these concepts remains insufficient. We also require policy changes to enforce course evaluations, and encourage lifelong learning to guarantee both practitioners' active working knowledge and update this where required. The latter requires action from the professional field by recalling students to offer continuous education, and normalizing membership of a professional organization which has the capabilities to enforce the principles of continuous learning and putting sustainability aspects into practice as an industry and scientific standard.

Furthermore, mass financial investments are being made into energy systems designed to last for the coming two to three generations. Without awareness of sustainability aspects, we cannot realistically hope to gain lasting progress as opposed to continuing with current practices which will cost more in the long term. It has been suggested by McCollum et al. [46] that funds should be massively reallocated in order to reach the Paris climate agreement targets. To effectively encourage reaching these goals, the consequences of such reallocation should implemented in the process of scientific funding as well. I therefore recommend two global improvements to transform our current generation of scientists, as well as foster our future generations, into being more deeply aware of the consequences of their research:

(1) Increase sustainability education, including environmental ethics, in all disciplines, countries, and tiers of education; for students, researchers, and policymakers.

(2) Make addressing sustainability considerations a compulsory component of research grants and funding (see also [47]).

Practically, one example of how this can take form concerns the International Science Council, formed in 2018 through merging two large existing scientific councils. 
As a leading authority on admirable scientific practices, a possible revision of their newly combined guidelines for ethical conduct could include the following:

- Advocate the professional and academic standards as the industry norm through governmental support, and encourage membership to this and other similarly regulated societies.

- Advocate the need to update one's knowledge regularly to all graduates, past and future, and stimulate initiatives by graduates and educational facilities to this end.

- Advocate the need to include sustainability concerns into grants and funding applications to policymakers, industry leaders, and other donor organizations, as a mandatory element.

- Advise members to shun grants and funding that does not require a review of how sustainable life cycles might be affected or studied.

As addressed by Bobrowsky et al. [35], such a code of conduct would have to be enforceable. If not the code would not be sustainable in itself. In line with these concepts, educators would review existing students and alumni about their knowledge, offering lifelong learning opportunities. Employers and professional societies would review employees' track record of such courses, and may implement their own systems to for instance rank people according to their implementation of sustainability aspects. Governments, policymakers, and funding organizations would require a minimum scoring threshold and award higher scoring employers with more funding, and provide subsidies for increasing education when necessary. Society and governments both would demand materials that are made with more sustainability aspects simultaneously in mind, demanding exploratory life cycle studies and linked funding.

The one caveat of this setup is that making sustainable materials by itself is insufficient in order to reach sustainable production goals. To truly reach transformative sustainable solutions, we should question human behavior before asking how a new material could be optimally sustainably designed. The logic of the entire life cycle should be questioned, including whether or not the product should be brought into existence in the first place. Policy changes are required to transform people's lifestyles $[1,35,47]$. Some go as far as to argue for sustainable population policies Ragnarsdóttir et al. [48]. Costanza et al. [49] have framed these issues in a novel way by comparing societies' unsustainable consumerism to that of individual addictions. In this view, societal addictions such as lifestyles with overconsumption relying on fossil fuels, overusing pesticides, economic aggrandizing, and overfishing, similar to an individual's cigarette or drug addictions, both have short term rewards yet continue to be used despite universal knowledge of their detrimental effects. To overcome problems with lifestyle transformations, Mulder et al. [3] state that technical innovation could be easier to implement than changing lifestyles on a global scale, while there remain many uncertainties regarding whether or not the changes technology may bring lead to increased sustainability. They recommend that institutions and lifestyles change simultaneously with technology, and material scientists be given concrete targets. They also point out how increased efficiency might lead to increased consumption and resource depletion, and believe that discussions on how products are used should be solved by public debate. This can be contrasted by Woodruff [11], who points out the disadvantages of prevalent ways of thinking, and the opportunities we have. Inhabitants of industrialized countries commonly believe that natural resources are free and can be consumed endlessly, that either nature will adapt to humanity's actions or technology can solve everything, and that a single person's daily activities have a negligible effect on the environment. At the same time, humans have a large amount of knowledge and skills, and can work together to reinvent how energy is produced and used, and how to address our needs for water, food, transportation etc. It is clear that, even if we do transform our existing education and professional ethics to align with the SDGs in practice, the effects of capitalist consumerism on the sustainable survival of our and many other species needs to be carefully examined by all human beings in order to fully reach the SDGs.

\subsection{Recommendations}

In this study, 36 material scientists were interviewed, or asked to fill out a questionnaire, regarding their own awareness of different sustainable design aspects related to the material they were developing. These results form an initial indication of material scientists' awareness and provide a basis to warrant whether a greater in depth study is required to ensure holistic awareness of all relevant sustainability concerns. The results of this study can be of use to: 
1 Policymakers; for assisting in the development of educational, industrial, and commercial policies, standards, and assessments.

2 Educators; for the development of curricula and to test if the material of those curricula is sufficiently implemented in real life settings.

3 Companies and research organizations; for compliance with international and local laws, codes, and policies on sustainability, for insight in the organizations' preparedness to successfully innovate and contribute to the circular economy and a sustainable global society.

4 Scientists and practitioners themselves; for reviewing their awareness and knowledge of key sustainability aspects, how these apply to the products they are developing and working with, and how they can make choices that increase the sustainability of their products' life cycles.

The results of this study may be applied by any of the four above listed actors in order to increase the awareness of the aspects of materials' sustainable life cycles among material scientists and other practitioners, or to directly encourage the development of materials with sustainable life cycles.

By performing a preliminary evaluation of the awareness of sustainability among material scientists, this study contributes to SDG 4: Quality Education [By 2030, ensure that all learners acquire the knowledge and skills needed to promote sustainable development, including, among others, through education for sustainable development and sustainable lifestyles, human rights, gender equality, promotion of a culture of peace and non-violence, global citizenship and appreciation of cultural diversity and of culture's contribution to sustainable development] and SDG 12: Responsible consumption and production [By 2030, ensure that people everywhere have the relevant information and awareness for sustainable development and lifestyles in harmony with nature] [5].

Still, Wolfram Alpha listed 8880 people employed as material scientist in the USA alone in 2009, and therefore this study has covered a small group of respondents compared to what the global number of practicing material scientists could be. This means that the results of this study need to be verified in a larger population of material scientists, and also outside of Japan. Furthermore, in order to assess the sense of responsibility in material scientist to their role in creating a sustainable society, a more detailed follow up study would need to ascertain the participants' study background and knowledge of sustainability aspects to a deeper level. More detailed background should include participant's nationality, place of study and degree, age and career stage, to determine any discernable patterns between awareness on the one hand, and training and culture on the other. In addition, participants' direct response as to the question of how they perceive their role in creating a sustainable society should be included. One important limitation to the currently questions chosen is that they cover neither education nor the ability of the scientists to act on their awareness, whether or not it is obtained from education or their own initiative. From a sustainability point of view, as well as from the various ethical guidelines for professional conduct, ideally a scientist would be themselves motivated to uphold these guidelines in practice. In reality limited resources, time, data, other tradeoffs and pressures may lead to less ideal circumstances and result in less ideal choices. Future questionnaires should additionally explore the organizational and funding support experienced by individual scientists. This would lead to a stronger understanding of the values material scientist apply in their work, and thereby which parts of educational theories become part of practice and which parts can be improved, either by previous omission or apparent redundancy. For instance, if scientists know the materials they are using is mined under inhumane circumstances, why did they not choose to purchase them from a different source? Which sustainability criteria, if any, do they apply during their decision making process? To what degree is data available on the environmental and socio-economic circumstances concerning their materials and processes, and to which level of detail should scientists try to obtain this? To what degree are scientists encouraged and supported by their organization, governments, and clients to act responsibly regarding sustainability aspects?

\section{Conclusion}

This study shows the responses of 36 material scientists of various nationalities pertaining to their awareness of various sustainability aspects relating to the material they are developing. The results show that, when imagining their material is successfully mass produced in the future, nearly all (86\%) participants have no idea of the amount of greenhouse gases that might be emitted during manufacturing. A further $44 \%, 36 \%$, and $35 \%$ have no idea about their 
material's recyclability, its longevity, or how many jobs its manufacturing might create respectively. These results imply that even though the principles of green chemistry and the SDGs have been taught more extensively over the past decades, this sample group of material scientists is not yet fully incorporating these aspects during the design phase of creating new materials.

As of yet there is little incentive for material scientists to pay more attention to the individual aspects of sustainable design, let alone to the entire spectrum of sustainability aspects at the same time. Therefore, these two global improvements are recommended in order to transform our current generation of scientists, as well as foster our future generations, into being more deeply aware of the consequences of their research:

(1) Increase sustainability education, including environmental ethics, in all disciplines, countries, and tiers of education; for students, researchers, and policymakers.

(2) Make addressing sustainability considerations a compulsory component of research grants and funding.

Since this was a small group of respondents compared to the global number of practicing material scientists, future research needs to verify the results of this study within a larger global population of material scientists. It also needs to be verified how these aspects might actually score and relate to education goals.

Funding This research did not receive any specific Grant from funding agencies in the public, commercial, or not-for-profit sectors.

\section{Compliance with ethical standards}

Conflict of interest The author declares no conflict of interest.

Open Access This article is licensed under a Creative Commons Attribution 4.0 International License, which permits use, sharing, adaptation, distribution and reproduction in any medium or format, as long as you give appropriate credit to the original author(s) and the source, provide a link to the Creative Commons licence, and indicate if changes were made. The images or other third party material in this article are included in the article's Creative Commons licence, unless indicated otherwise in a credit line to the material. If material is not included in the article's Creative Commons licence and your intended use is not permitted by statutory regulation or exceeds the permitted use, you will need to obtain permission directly from the copyright holder. To view a copy of this licence, visit http://creativecommons .org/licenses/by/4.0/.

\section{Appendix A}

Below is an abbreviated version of the questionnaires used during the second and third event. The event titles, study background, handling of personal information, and contact procedures have been removed to show only the instructions and questions themselves.

\section{Questionnaire on Sustainability of Research Materials}

Instructions:

Please take a moment to think about the material, device, or product you are developing or improving. Imagine it will be highly successful in the near future and implemented worldwide. What sort of effects may this have?

1. What is the practical application of the material/product you are working on? 
2. How much more efficient is this material in comparison to conventional materials?

\begin{tabular}{|c|c|c|c|c|c|}
\hline$\square$ No ideat & $\begin{array}{l}\square \text { Orders of } \\
\text { mag- } \\
\text { nitude } \\
\text { worse }\end{array}$ & $\square$ Worse & $\begin{array}{l}\square \text { Com- } \\
\text { parable }\end{array}$ & $\begin{array}{r}\square 2-10 \\
\text { times } \\
\text { more }\end{array}$ & $\begin{array}{c}\square 100 \\
\text { times } \\
\text { more }\end{array}$ \\
\hline
\end{tabular}

3. How much longer is the lifetime of this material in comparison to conventional materials?

\begin{tabular}{cccc}
\hline No idea & $\begin{array}{c}\square \text { Orders of } \\
\text { mag- } \\
\text { nitude } \\
\text { worse }\end{array}$ & $\begin{array}{c}\square \text { Worse } \\
\text { parable }\end{array}$ & $\square$ Years \\
podecades
\end{tabular}

4. How hard to obtain are the basic materials?

\begin{tabular}{cccccc}
\hline$\square$ No idea & $\square$ Very & $\square$ Quite & $\square$ Aver- & $\square$ Rea- & $\square$ Easily \\
& difficult & difficult & $\begin{array}{c}\text { age dif- } \\
\text { ficulty }\end{array}$ & $\begin{array}{l}\text { son- } \\
\text { ably }\end{array}$ & obtainable \\
& & & obtain- \\
& & & able
\end{tabular}

5. How abundant is this material when considering future generations using your material/product?

\begin{tabular}{cccccc}
\hline $\begin{array}{c}\square \text { No } \\
\text { idea }\end{array}$ & $\begin{array}{c}\square \text { Very } \\
\text { rare }\end{array}$ & $\begin{array}{c}\square \text { Rather } \\
\text { rare }\end{array}$ & $\begin{array}{c}\square \text { Com- } \\
\text { monly } \\
\text { available }\end{array}$ & $\begin{array}{c}\square \text { High } \\
\text { abun- } \\
\text { dance }\end{array}$ & $\begin{array}{c}\square \text { Overly } \\
\text { abundant }\end{array}$ \\
\end{tabular}

6. How many greenhouse gases are released during the production process of this material/product?

\begin{tabular}{cccccl}
\hline$\square$ No & $\square$ Mas- & $\square 50,000 \mathrm{~kg}$ & $\square 500 \mathrm{~kg}$ & $\square 50 \mathrm{~kg}$ & $\square$ Few to \\
idea & sive-500,000 kg & $\mathrm{CO}_{2}$ & $\mathrm{CO}_{2}$ & $\mathrm{CO}_{2}$ & none-5 kg \\
& $\mathrm{CO}_{2}$ equivalent & equiva- & equiva- & equiva- & $\mathrm{CO}_{2}$ \\
& & lent (2-3 & lent & lent (pc) & equivalent \\
& & cars) & & ears & $\begin{array}{l}\text { (food } \\
\text { stuffs) }\end{array}$ \\
& & & & & \\
\hline
\end{tabular}

7. How toxic are the materials used to humans and the environment?

\begin{tabular}{|c|c|c|c|c|c|}
\hline $\begin{array}{l}\square \text { No } \\
\text { idea }\end{array}$ & $\begin{array}{l}\text { Numer- } \\
\text { ous } \\
\text { adverse } \\
\text { effects }\end{array}$ & $\begin{array}{c}\square \text { Several } \\
\text { adverse } \\
\text { effects }\end{array}$ & $\begin{array}{c}\square \text { Some } \\
\text { adverse } \\
\text { effects }\end{array}$ & $\begin{array}{l}\square \text { Few } \\
\text { adverse } \\
\text { effects }\end{array}$ & $\begin{array}{l}\square \text { No } \\
\text { adverse } \\
\text { effects }\end{array}$ \\
\hline
\end{tabular}

8. How much of this material can be recycled at the end of its life cycle?

\begin{tabular}{llllll}
\hline$\square$ No idea & $\square \pm 0-5 \%$ & $\square \pm 25 \%$ & $\square \pm 50 \%$ & $\square \pm 75 \%$ & $\square$ Up to $100 \%$
\end{tabular}

9. How much training and education would be required to start mass production of this material?

\begin{tabular}{cccccc}
\hline$\square$ No idea & $\begin{array}{c}\square \text { Beyond } \\
\text { univer- } \\
\text { sity }\end{array}$ & $\begin{array}{c}\square \text { Master's } \\
\text { Degree }\end{array}$ & $\begin{array}{c}\square \text { Bach- } \\
\text { elor's } \\
\text { Degree }\end{array}$ & $\begin{array}{c}\square \text { High } \\
\text { school }\end{array}$ & $\begin{array}{c}\text { diploma } \\
\text { None }\end{array}$ \\
& & Der &
\end{tabular}

10. How many new jobs would be created in order to mass produce and maintain the use of this material?

\begin{tabular}{|c|c|c|c|c|c|}
\hline $\begin{array}{l}\text { No } \\
\text { idea }\end{array}$ & $\begin{array}{r}\square \text { Few- } \\
100 \mathrm{~s}\end{array}$ & $\square 1000 \mathrm{~s}$ & $\square 10,000 \mathrm{~s}$ & $\square 100,000 \mathrm{~s}$ & $\square 1,000,000 \mathrm{~s}$ \\
\hline
\end{tabular}

\section{References}

1. Akenji L, Chen H (2016) A framework for shaping sustainable lifestyles, determinants and strategies. UNEP. http://wedoc s.unep.org/handle/20.500.11822/9995. Accessed 17 Apr 2020

2. Venables JD et al. (unknown) Materials Science. Encyclopedia Brittanica. https://www.britannica.com/technology/materialsscience. Accessed 17 Apr 2020

3. Mulder K, Ferrer D, Van Lente H (2013) What is Sustainable Technology? In: Mulder K, Ferrer D, Van Lente $\mathrm{H}$ (eds) What is sustainable technology? Perceptions, paradoxes and Possibilities. Greenleaf Publishing, Sheffield, pp 1-7

4. PwC ( $x x x x)$ United Nations Industrial Development Organization (UNIDO), Global Manufacturing and Industrialization Summit (GMIS) (2017) Delivering the Sustainable Development Goals, seizing the opportunity in global Manufacturing. https://www.pwc.com/m1/en/publications/delivering-susta inable-development-goals.html. Accessed 4 Jan 2019

5. UN (unknown) Goal 12: Ensure sustainable consumption and production patterns. https://www.un.org/sustainabledeve lopment/sustainable-consumption-production/. Accessed 17 Apr 2020

6. Skerlos SJ, Morrow WR, Michalek JJ (2006) Sustainable design engineering and science: selected challenges and case studies. In: Abraham M (ed) Sustainability science and engineering. Elsevier Science, London

7. UNEP (2012) Greening the economy-through life cycle thinking. UNEP, Paris

8. UNEP (2016) Product Sustainability Information: State of Play and Way Forward. UNEP

9. Bringezu S et al. (2017) Assessing global resource use: a systems approach to resource efficiency and pollution reduction. A Report of the International Resource Panel. United Nations Environment Programme. Nairobi, Kenya

10. Ramani K, Ramanujan D, Bernstein WZ, Zhao F, Sutherland J, Handwerker C, Choi JK, Kim H, Thurston D (2010) Integrated sustainable life cycle design: a review. J Mech Des 132(9):091004. https://doi.org/10.1115/1.4002308

11. Woodruff PH (2006) Educating engineers to create a sustainable future. J Environ Eng ASCE. https://doi.org/10.1061/ (ASCE)0733-9372(2006)132:4(434)

12. Garg A (2012) Sustainable green chemistry for better living: a challenge of 21st century. Int Arch Appl Sci Technol 3(2):1-13

13. Latha D, Prabu P, Gnanamoorthy G et al (2019) Size-dependent catalytic property of gold nanoparticle mediated by Justicia adhatoda leaf extract. SN Appl Sci 1:134. https://doi. org/10.1007/s42452-018-0148-y

14. Palai PK, Mondal A, Chakraborti CK et al (2019) Green synthesized amino-PEGylated silver decorated graphene nanoplatform as a tumor-targeted controlled drug delivery system. SN Appl Sci 1:269. https://doi.org/10.1007/s42452-019-0287-9

15. Karuppannan Gopalraj S, Kärki T (2020) A review on the recycling of waste carbon fibre/glass fibre-reinforced composites: fibre recovery, properties and life-cycle analysis. SN Appl Sci 2:433. https://doi.org/10.1007/s42452-020-2195-4

16. Ratti R (2020) Industrial applications of green chemistry: status, challenges and prospects. SN Appl Sci 2:263. https://doi. org/10.1007/s42452-020-2019-6

17. Cummings SD (2013) ConfChem conference on educating the next generation: Green and sustainable chemistry-solar energy: a chemistry course on sustainability for general science education and quantitative reasoning. J Chem Educ 90:523-524. https://doi.org/10.1021/ed200589u 
18. Hill J, Kumar DD, Verma RK (2013) Challenges for chemical education: engaging with green chemistry and environmental sustainability. J Am Inst Chem 86(1):24-31

19. Kim KH (1999) Environmental reforms of material science education in the 21st century. Mater Chem Phys 61(1):14-17. https:// doi.org/10.1016/S0254-0584(99)00106-6

20. Arnold C (2003) Environmental Materials. In: P. J. Goodhew (Ed), Teaching Materials Engineering, an updated guide, UK Centre for Materials Education

21. Waters C, Luster-Teasley S (2013) Student Case Study Creation for the Sustainable Side of Material Science. In: 120th ASEE annual conference and exposition (p. Paper ID\#6104)

22. Nossoni G (2014) An innovative way to teach sustainability in Civil Engineering Material Class. Presented at the American Society for Engineering Education, Indianapolis, IN, USA, Paper ID \#8759

23. Kirchain RE, Gregory JR, Olivetti EA (2017) Environmental lifecycle assessment. Nat Mater. https://doi.org/10.1038/nmat4923

24. Telenko C, O'Rourke JM, Seepersad CC, Webber ME (2016) A compilation of design for environment guidelines. ASME J Mech Des. https://doi.org/10.1115/1.4032095

25. National Science Foundation (2008) The future of materials science and materials engineering education. In: Workshop on materials science and materials engineering education, p. 57.

26. Heard RA (2012) Technology impact-from Utopia to Wasteland. In: Presented at the American Society for Engineering Education, San Antonio, TX, USA, AC 2012-4041

27. Lesar R, Chen KC, Apelian D (2012) Teaching sustainable development in materials science and engineering. MRS Bull 37(4):449-454. https://doi.org/10.1557/mrs.2012.9

28. Aurandt JL, Butler EC (2011) Sustainability education: approaches for incorporating sustainability into the undergraduate curriculum. J Prof Issues Eng Educ Practice 137(2):102-106. https://doi.org/10.1061/(ASCE)El.1943-5541.0000049

29. Rojter J (2011) Developing sustainability consciousness in engineering curriculum through materials education. Energy Procedia 16:810-815. https://doi.org/10.1016/j.egypro.2012.01.130

30. Anastas PT, Zimmerman JB (2003) Design through the twelve principles of green engineering. Environ Sci Technol 37(5):94A-101A

31. NSPE code of ethics for engineers. https://www.nspe.org/resou rces/ethics/code-ethics. Accessed 30 Jan 2019

32. Code of Ethics of Engineers, as referenced in the ASME Constitution, Article C2.1.1. https://community.asme.org/colorado_secti on/w/wiki/8080.code-of-ethics.aspx. Accessed 30 Jan 2019

33. IEEE Policies, Section 7-professional activities (Part A-IEEE Policies), 7.8 IEEE Code of Ethics. https://www.ieee.org/about /corporate/governance/p7-8.html. Accessed 30 Jan 2019

34. David DSY, Kollie MM (2017) Engineering ethics: an integrated approach. In: Proceedings of ISER 78th international conference

35. Bobrowsky P, Cronin VS, Di Capua G, Kieffer SW, Peppoloni S (2017) The Emerging Field of Geoethics. In: Gundersen LC (ed) Scientific integrity and ethics with applications to the geosciences, Special Publication American Geophysical Union. Wiley, New York

36. Blewitt J (2010) Higher education for a sustainable world. Educ Train. https://doi.org/10.1108/00400911011068432

37. Jenkins K, McCauley D, Heffron R, Stephan H, Rehner R (2016) Energy justice: a conceptual review. Energy Res Soc Sci 11:174182. https://doi.org/10.1016/j.erss.2015.10.004
38. Otaki $\mathrm{M}$ (2015) Local altruism as an environmental ethic in $\mathrm{CO}_{2}$ emissions control. Atmos Clim Sci 05(04):433-440. https://doi. org/10.4236/acs.2015.54035

39. Wackernagel $M$, Schulz NB, Deumling $D$, Linares $A C$, Jenkins M, Kapos V, Monfreda C, Loh J, Myers N, Norgaard R, Randers $J$ (2002) Tracking the ecological overshoot of the human economy. Proc Natl Acad Sci 99(14):9266-9271. https://doi.org/10.1 111/j.1445-5994.2012.02718.x

40. Runnalls D (2008) Why Aren't We There Yet? Twenty years of sustainable development. International Institute for Sustainable Development, Winnipeg, Manitoba, Canada. https://www. iisd.org/sites/default/files/publications/com_there_yet.pdf. Accessed 15 Jan 2019

41. Dernbach JC, Brown DA (2009) The ethical responsibility to reduce energy consumption. SSRN. https://doi.org/10.2139/ ssrn. 1464875

42. van der Voet E, Salminen R, Eckelman M, Mudd G, Norgate T, Hischier R (2013) Environmental risks and challenges of anthropogenic metals flows and cycles. In: A Report of the Working Group on the Global Metal Flows to the International Resource Panel. UNEP

43. Bringezu S et al. (2017) Assessing global resource use: a systems approach to resource efficiency and pollution reduction. In: A Report of the International Resource Panel. United Nations Environment Programme. Nairobi, Kenya

44. Krosnick JA, Presser S (2009) Question and questionnaire design. In: Wright JD, Van Marsden P (eds) Handbook of survey research. Elsevier, San Diego, pp 263-314

45. Rovers D (2017) Duurzaamheid is nog ver weg in het klaslokaal-(Dutch: Sustainability is still far away from the classroom), pedagogical academy for primary education (pabo), Newspaper Trouw. https://www.trouw.nl/home/duurzaamhe id-is-nog-ver-weg-in-het-klaslokaal a9b0e3e7/. Accessed 15 Jan 2019

46. McCollum DL et al (2018) Energy investment needs for fulfilling the Paris Agreement and achieving the Sustainable Development Goals. Nat Energy 3(7):589-599. https://doi.org/10.1038/ s41560-018-0179-z

47. Ali SH (2018) The materials science imperative in meeting the Sustainable Development Goals. Nat Mater 17:1052-1053. https ://doi.org/10.1038/s41563-018-0228-9

48. Ragnarsdóttir KV, Sverdrup HU, Koca D (2012) Assessing Long Term Sustainability of Global Supply of Natural Resources and Materials, Sustainable Development - Energy, Engineering and Technologies - Manufacturing and Environment. In: Prof. Chaouki Ghenai (ed), ISBN: 978-953-51-0165-9, InTech, Available from: http://www.intechopen.com/books/sustainable-devel opment-energy-engineering-and-technologies-manufactur ing-and-environment/rare-metals-burnoff-rates-versus-syste m-dynamics-of-metal-sustainability. Accessed 17 Apr 2020

49. Costanza R, Atkins PWB, Bolton M, Cork S, Grigg NJ, Kasser T, Kubiszewski I (2017) Overcoming societal addictions: what can we learn from individual therapies? Ecol Econ. https://doi. org/10.1016/j.ecolecon.2016.09.023

Publisher's Note Springer Nature remains neutral with regard to jurisdictional claims in published maps and institutional affiliations. 